\title{
Perbaikan Kemampuan Pemecahan Masalah Matematika melalui Model Pembelajaran Kooperatif Tipe STAD
}

\author{
Aswin Saputra* dan Endaryono \\ Program Studi Informatika, Universitas Indraprasta PGRI, Indonesia \\ *saputraaswin133@gmail.com
}

\begin{abstract}
Abstrak
Penelitian ini dilakukan untuk mengetahui nilai peningkatan kemampuan pemecahan masalah matematika siswa kelas III tingkat sekolah dasar melalui model pembelajaran kooperatif tipe STAD di SDN Kapuk Muara 01. Penelitian yang digunakan merupakan penelitian tindakan kelas atau dikenal dengan classroom action research (CAR), yaitu suatu tindakan yang dilakukan oleh guru dan peneliti untuk memperbaiki pengajaran dengan cara melakukan perubahan dan mempelajari akibat dari perubahan itu. Teknik yang digunakan dalam pengumpulan data adalah tes akhir siklus dan observasi. Dari pelaksanaan penelitian, didapatkan pada siklus I hasil belajar siswa adalah adalah $51.163 \%$. Selanjutnya pada siklus II dilakukan perbaikan dan didapatkan hasil belajar siswa adalah 90.69\%. Dari siklus II terlihat adanya perbaikan dan peningkatan hasil belajar siswa. Penelitian menunjukkan bahwa proses pembelajaran matematika dengan penerapan model kooperatif tipe STAD (Student Team Achievement Divisions) mampu memperbaiki penguasaan konsep siswa menjadi lebih baik
\end{abstract}

Kata kunci: pemecahan masalah, pembelajaran kooperatif, tipe STAD

\begin{abstract}
This study was conducted to determine the value of increasing the ability to solve mathematical problem class III students at the elementary school level through the STAD type cooperative learning model at SDN Kapuk Muara 01. The research used was classroom action research or known as classroom action research (CAR), which is an action that conducted by teachers and researchers to improve teaching by making changes and studying the effects of those changes. The technique used in data collection is the end of the cycle test and observation. From the implementation of the study, obtained in the first cycle of student learning outcomes is $51.163 \%$. Furthermore, in the second cycle an improvement was made and the student learning outcomes were $90.69 \%$. From the second cycle seen improvements and student learning outcomes. Research shows that the process of learning mathematics by applying the STAD (Student Team Achievement Divisions) cooperative model can improve students' mastery of concepts better
\end{abstract}

Keyword: problem solving, cooperative learning, STAD type.

\section{PENDAHULUAN}

Pendidikan yang bermutu merupakan salah satu prioritas utama dalam pembangunan nasional. Pendidikan yang menghasilkan perubahan sikap dan tingkah laku manusia baik yang berupa pengetahuan maupun keterampilan akan membawa kemajuan suatu bangsa. Pentingnya pendidikan inilah yang menuntut adanya proses pendidikan yang optimal sehingga menghasilkan pendidikan yang bermutu. Dalam PISA (Program for International Student Assessment) 2015, 
Indonesia memiliki skor bidang sains 403, skor bidang matematika 386, dan skor bidang membaca 297. Indonesia menempati ranking pada urutan sanis 62 , ranking 63 bidang matematika dan ranking 64 bidang membaca. Survey yang dilakukan oleh PISA ini dari 70 negara. Hal ini bermakna Indonesia termasuk kategori 10 urutan terbawah (OECD, 2016)

Rendahnya nilai hasil belajar siswa juga terjadi pada siswa kelas III SDN Kapuk Muara 01 terutama pada pembelajaran matematika. Sebagai contoh, saat guru memberikan ulangan harian materi operasi hitung campuran maka kebanyakan siswa salah mengoperasikan perhitungan. Akibatnya lebih dari $70 \%$ siswa belum tuntas. Rerata ulangan harian kurang dari batas kriteria Ketuntasan minimal (KKM) yaitu 70. Kriteria ketuntasan minila (KKM) adalah kriteria paling rendah untuk menyatakan peserta didik mencapai ketuntasan. Data hasil ulangan harian materi operasi hitung campuran dapat dilihat pada Tabel 1.

Tabel 1. Rerata hasil ulangan harian materi operasi hitung campuran

\begin{tabular}{ccc}
\hline Tahun Pelajaran & Jumlah siswa & Rerata nilai \\
\hline 2013 / 2014 & 31 & 50 \\
\hline 2014 / 2015 & 32 & 52
\end{tabular}

Sumber: Daftar Nilai Guru kelas III SDN Kapuk Muara 01 Jakarta Utara

Data pada Tabel 1 menunjukkan bahwa kemampuan pemecahan masalah matematika siswa kelas III masih rendah. Hal ini teridentifikasi dari kegiatan menyelesaikan soal-soal yang menuntut kemampuan siswa untuk berpikir kritis dan logis, mayoritas siswa yang belum mampu memahami apa maksud yang terdapat dalam soal tersebut. Faktor yang menyebabkan rendahnya hasil belajar siswa dikarenakan guru dalam menerangkan materi matematika tidak menarik perhatian siswa. Guru cenderung menggunakan model pembelajaran konvensional sehingga mengakibatkan sebagian siswa bersikap pasif selama proses belajar mengajar berlangsung. Tidak tepat dalam menggunakan model pembelajaran dapat berdampak pada repson siswa yang menjadi rendah atau pasif. Hal itu menjadikan kondisi belajar mengajar tidak kondusif yang dapat menimbulkan tidak adanya minat belajar siswa terhadap pelajaran matematika. Kondisi ini mengakibatkan hasil belajar matematika yang diperoleh siswa rendah.

Satu dari tujuan pembelajaran matematika adalah agar siswa mampu memecahkan permasalahan matematka dalam kehidupan sehari-hari. Oleh sebab itu kemamapuan penguasaan konsep dan pemecahan masalah matematika siswa adalah penting. Berdasarkan paparan di atas, peneliti tertarik untuk melakukan Penelitian Tindakan Kelas (PTK) dengan judul "Perbaikan Kemampuan Pemecahan Masalah Matematika Siswa Kelas III di SDN Kapuk Muara 01 melalui Model Pembelajaran Kooperatif Tipe STAD”. Tipe STAD (Student Team Achievement Divisions) adalah model belajar pendekatan pembelajaran kooperatif didalamnya terdapat aktifitas dan interaksi antara siswa sehingga terjadi saling membantu dan saling memotivasi untuk penguasaan materi pembelajaran (Widyantini, 2008; Nurimani, 2016; Firmansayah, 2016; Zuhriyah, 2017).

Penelitian ini dilakukan karena perlu adanya peningkatan kemampuan kemampuan pemecahan masalah matematika siswa. Beberapa sasaran yang akan dicapai dalam pembelajaran matematika adalah memahami konsep matematika, menjelaskan keterkaitan antarkonsep, dan menerapkan konsep atau algoritma 
secara luwes, akurat, dan mampu memecahkan permasalahan yang berkaitan dengan operasi hitung campuran.

\section{METODE PENELITIAN}

Metode yang digunakan dalam penelitian ini adalah metode penelitian tindakan kelas (Classrom Action Research). Penelitian tindakan kelas (PTK) merupakan penelitian tindakan yang dilakukan yang bertujuan untuk memperbaiki mutu praktik pembelajaran di kelas (Arikunto, Suhardjono \& Supardi, 2015). Langkahlangkah pengujian tindakan yang digunakan dalam penelitian ini mengacu pada model yang dikembangkan oleh Kemmis, McTaggart \& Nixon (2013). Dalam model ini, setiap siklus terdiri dari empat komponen yang meliputi: perencanaan, tindakan, observasi, dan refleksi (Aqib, Diniati, Jaiyaroh \& Khotimah, 2008).

Desain penelitian ini adalah One-Pretest-Posttest Design. Desain tersebut paling banyak digunakan pada penelitian tindakan untuk peningkatan kinerja. Subjek yang akan dikenai tindakan adalah karyawan di unit kerja tersebut, atau murid di dalam satu kelas kalau penelitian tersebut merupakan penelitian tindakan kelas. Peneliti sebagai pelaku kerja dapat berkolaborasi dengan ahli metode penelitian (Sugiyono, 2015). Desain penelitian yang dilakukan dapat dilihat pada Tabel 2

Tabel 2. Desain Penelitian

\begin{tabular}{ll}
\hline $\mathrm{O}_{1} \times \mathrm{O}_{2}$ & Keterangan: \\
& $\mathrm{O}_{1}=$ Nilai pretes \\
& $\mathrm{O}_{2}=$ Nilai Postes \\
& Pengaruh tindakan terhadap prestasi siswa $=\left(\mathrm{O}_{2}-\mathrm{O}_{1}\right)$ \\
\hline
\end{tabular}

Dalam penelitian tindakan kelas, pelaksanaan dilakukan tiga pertemuan untuk satu siklus. Pertemuan pertama baru mencoba memperkenalkan metode pembelajaran. Pertemuan kedua melakukan perbaikan jika saat pertemuan pertama ada yang kurang sesuai. Dan pertemuan ketiga untuk memantapkan pembelajaran menggunakan metode pembelajaran. Jika pengulangan menggunakan pembelajaran dalam tiga pertemuan, maka materi harus berlanjut dan metodenya harus sama dari pertemuan ke pertemuan dan dari siklus ke siklus selanjutnya. Jika kompetensi dasar (KD) yang diajarkan memerlukan waktu dua pertemuan, maka untuk pertemuan ketiga guru dapat mengajarkan materi dari KD lain dan seterusnya. Apabila kriteria ketuntasan minimal (KKM) belum tercapai saat siklus belum selesai, maka guru boleh melakukan remedial dan pelaksanaannya dilakukan di luar jam belajar. Hal ini bertujuan agar tidak mengganggu jalanya PTK (Arikunto dkk., 2015).

Penelitian ini dilakukan dengan tiga pertemuan untuk satu siklus. Pada pertemuan pertama ilakukan kegiatan untuk memperkenalkan model pembelajaran kooperatif tipe STAD. Pertemuan kedua dilakukan perbaikan jika saat pertemuan pertama ada yang kurang pas. Pertemuan ketiga dilakukan pemantapan proses pembelajaran menggunakan model pembelajaran kooperatif tipe STAD. Pengujian tindakan dirancang sesuai dengan karakteristik penelitian tindakan kelas (PTK) dan dibatasi sampai pada dua siklus. Setiap siklus terdiri dari empat tahap utama yaitu: (a) tahap perencanaan (planing), (b) tahap pelaksanaan 
tindakan (action), (c) tahap observasi (observation), (d) tahap analisis dan refleksi (reflection) (Eminingsih, 2013).

Dalam setiap siklus dirancang dengan menerapkan model pembelajaran kooperatif tipe STAD untuk mencapai tujuan pembelajaran matematika. Keberhasilan penelitian dilihat dari peningkatan hasil belajarnya dari setiap siklusnya.

Teknik Sampling dalam penelitian ini yaitu menggunakan teknik observasi terhadap siswa di kelas. Dalam penelitian PTK ini teknik pengumpulan datanya adalah: (a) data awal, untuk mengetahui tingkat kemampuan siswa dalam memahami pelajaran; (b) data hasil belajar siswa dari nilai lembar kerja siswa (lks) dan hasil tes dari setiap akhir siklus; (c) observasi terhadap proses pembelajaran dan respon siswa; (d) data tentang refleksi perubahan perubahan yang terjadi di kelas, yang diperoleh melalui catatan lapangan dan wawancara.

Ketuntasan belajar siswa berdasarkan pada petunjuk teknis pelaksanaan belajar mengajar Kurikulum Tingkat Satuan Pendidikan (KTSP) SDN Kapuk Muara 01 pada mata pelajaran matematika, masing-masing siswa dinyatakan tuntas belajar jika mencapai kriteria ketuntasan minimal (KKM) dengan nilai 65.

Penelitian ini menggunakan teknik triangulasi dengan jalan memanfaatkan peneliti untuk keperluan pengecekan kembali derajat kepercayaan data. Pemanfaatan dalam hal ini adalah guru matematika kelas III dan peneliti dapat membantu mengurangi kesalahan dalam pengumpulan data. Setelah data dan informasi yang diperlukan terkumpul seluruhya, langkah selanjutnya adalah analisis data. Sesuai dengan jenis datanya, maka untuk analisisnya akan digunakan teknik analisis deskriptif kuanlitatif.

Untuk melihat tingkat keberhasilan atau persentase keberhasilan siswa setelah pembelajaran setiap putarannya dilakukan dengan cara memberikan evaluasi berupa soal tes tertulis pada setiap akhir putaran. Instrumen yang akan digunakan untuk pengumpulan dan penelitian ini adalah: (a) lembar observasi terhadap proses pembelajaran dengan menggunakan model pembelajaran kooperatif tipe stad, (b) lembar observasi respon siswa, (c) lembar kerja siswa berupa soal-soal yang berhubungan dengan materi yang diberikan kepada siswa, (d) lembar penilaian hasil belajar siswa, dan (e) lembar wawancara yang digunakan untuk mempertegas dan melengkapi data yang diperoleh dari observasi dan tes.

Kriteria keberhasilan dari pemberian tindakan ini adalah apabila pencapaian rata-rata kelas pada setiap siklus mengalami peningkatan signifikan dari prasiklus atau data awal sampai pada siklus ke II, siswa yang memenuhi KKM lebih dari 80\% pada siklus ke II di kelas III SDN Kapuk Muara 01.

\section{HASIL DAN PEMBAHASAN}

Seperti telah dijelaskan sebelumnya, penelitian tindakan kelas ini dilakukan dalam dua siklus. Pelaksanaan prosedur penelitian yang akan dilakukan oleh peneliti adalah sebagai berikut.

\section{Tahapan Pelaksanaan Siklus I}

Pada tahap perencanaan tindakan, kegiatan yang dilakukan adalah: (a) guru menyusun silabus yang berkaitan dengan materi operasi hitung campuran, (b) guru merancang skenario pembelajaran yang dapat digunakan dalam model 
pembelajaran kooperatif tipe stad, (c) merancang alat pengumpul data berupa tes dan digunakan untuk mengetahui penguasaan konsep siswa yang berkaitan dengan materi operasi hitung campuran.

Pada tahap pelaksanaan tindakan, kegiatan dalam pelaksanaannya adalah: (a) memberikan penjelasan secara umum tentang materi yang sampaikan dengan menggunakan model pembelajaran kooperatif tipe STAD agar menstimulasi rasa ingin tahu siswa, mendorong siswa agar aktif dalam mengikuti pembelajaran, mengamati dan mencatat siswa yang berpartisipasi aktif dalam pembelajaran, mengumpulkan hasil pengujian yang diperoleh siswa dalam mengerjakan tugas dan menganalisis hasil tes yang diberikan setelah siswa diajar dengan model pembelajaran kooperatif tipe STAD; (b) guru mengajar sesuai dengan skenario pembelajaran klasikal yang telah dirancang dan mencatat kegiatan-kegiatan yang dilakukan oleh masing-masing siswa; (c) guru memberikan evaluasi pada siswa untuk mengetahui pemahaman siswa berkaitan dengan materi operasi hitung campuran.

Pada tahap observasi tindakan, peneliti mengobservasi semua kejadian yang terjadi pada saat siswa mengikuti pembelajaran dan menanyakan pada siswa yang pasif dalam pembelajaran tentang kesulitan-kesulitan yang dihadapinya.

Pada tahap refleksi, guru dan peneliti menganalisis hasil pekerjaan siswa dan hasil observasi yang dilakukan pada siswa guna menentukan langkah berikutnya. Peneliti membuat pengelompokkan siswa berdasarkan pada hasil yang didapatkan siswa pada evaluasi yang dilakukan. Hasil dari siklus I dapat dilihat pada Tabel 3.

Tabel 3. Nilai Tes Siklus I

\begin{tabular}{ccc}
\hline Interval Nilai & Frekuensi & Presentasi $(\%)$ \\
\hline $30-39$ & 4 & 12,5 \\
\hline $40-49$ & 4 & 12,5 \\
\hline $50-59$ & 7 & 21,7 \\
\hline $60-69$ & 8 & 25 \\
\hline $70-79$ & 3 & 9,3 \\
\hline $80-89$ & 4 & 12,5 \\
\hline $90-99$ & 2 & 6,5 \\
\hline Jumlah & 32 & 100 \\
\hline
\end{tabular}

Berdasarkan pengamatan yang telah dilakukan selama kegiatan siklus I, siswa kurang memahami soal mengenai materi operasi hitung campuran. Siswa kesulitan untuk menentukan menyelesaikan setiap tipe soal yang diberikan. Hal ini dikarenakan kurang pahamanya siswa mengenai materi operasi hitung. Diskusi kelompok juga belum berjalan efektif dan masih terdapat siswa yang pasif saat berdiskusi dengan teman dalam kelompoknya. Maka peneliti dan guru sepakat untuk mengulang materi, agar ditindak lanjuti ke siklus II

\section{Tahapan Pelaksanaan Siklus II}

Tahap perencanaan tindakan, kegiatan yang dilakukan adalah: (a) Mempersiapkan fasilitas dan sarana yaitu dengna membuat kelompok siswa dengan penyebaran siswa yang menguasai materi awal yaitu materi yang telah disampaikan pada siklus sebelumnya; (b) Membuat pengurus pada masing-masing kelompok yang 
fasilitator, pencatat, juru bicara, dan pengatur waktu; (c) Membuat bahan ajar yang akan disampaikan pada masing-masing kelompok untuk didiskusikan.

Pada tahap pelaksanaan tindakan, kegiatan dalam pelaksanaannya adalah: (a) peneliti memberikan penjelasan tentang pokok bahasan operasi hitung campuran yang akan dipelajari serta menjelaskan kegiatan yang akan dilaksanakan berkaitan dengan pengajaran dalam teknik menstimulasi siswa untuk belajar bersama dalam kelompok; (b) siswa yang telah menguasai materi awal disiklus i diminta memimpin pembahasan bahan ajar yang diberikan peneliti, kemudian bahan ajar yang diberikan berisi tugas memecahkan masalah tindak lanjut dari siklus i; (c) memberi kesempatan kepada masing-masing kelompok untuk menyajikan hasil diskusi; (d) pembahasan materi ajar yang siswa dalam satu kelas mengalami kesulitan atau pun salah dalam apersepsinya; (e) mengevaluasi siswa untuk mengetahui kemampuan siswa dalam menguasai pengerjaan soal operasi hitung campuran.

Pada tahap observasi tindakan, guru mencatat hasil-hasil yang diperoleh siswa serta mencatat kesalahan-kesalahan yang dilakukan siswa dalam mengerjakan masalah yang berkaitan dengan bahan ajar yang diberikan. Kemudian guru mencatat kesalahan-kesalahan yang dilakukan siswa dalam menyelesaikan masalah pada bahan ajar yang diberikan.

Pada tahap refleksi, peneliti dan guru membuat inventarisasi kesulitan yang dilakukan siswa dalam menyelesaikan masalah pada bahan ajar yang diberikan serta mendata siswa yang telah mampu menyelesaikan soal evaluasi dan mampu mendapatkan nilai di atas standar KKM. Hasil dari siklus II dapat dilihat pada Tabel 4.

Tabel 4. Nilai Tes Siklus II

\begin{tabular}{ccc}
\hline Interval Nilai & Frekuensi & Presentasi (\%) \\
\hline $30-39$ & 2 & 6,25 \\
\hline $60-69$ & 12 & 37,50 \\
\hline $70-79$ & 10 & 31,25 \\
\hline $80-89$ & 5 & 15,70 \\
\hline $90-99$ & 3 & 9,30 \\
\hline Jumlah & 32 & 100 \\
\hline
\end{tabular}

Berdasarkan hasil tes pada siklus II dapat diketahui sudah ada perbaikan atau peningkatan yang baik pada penguasaan konsep matematika siswa karena dari 32 siswa hanya terdapat dua siswa yang nilai antara 30-39, untuk nilai antara 60-69 (di atas KKM) nilai dan sisanya memperoleh nilai di atas KKM. Berdasarkan pengamatan yang telah dilakukan selama siklus II, diskusi kelompok berjalan aktif, suasana di kelas juga tertib dan tenang karena hampir seluruh siswa aktif berdiskusi dalam kelompoknya. Motivasi belajar siswa juga meningkat dengan penerapan model pembelajaran kooperatif tipe STAD ini.

\section{Pembahasan}

Pada perencanaan, guru menentukan pokok bahasan tentang operasi hitung campuran dan dalam pelaksanaan tindakan, peneliti melaksanakan pembelajaran sesuai skenario yang telah dibuat. Guru dalam kegiatan observasi mengacu pada lembar observasi. Pada tahap yang terakhir yaitu refleksi, peneliti melakukan 
evaluasi dan membahas hasil evaluasi tersebut dan mencermatinya. Sesuai langkah-langkah model pembelajaran kooperatif tipe STAD, yaitu: (a) guru menyampaikan materi yang akan didiskusikan; (b) siswa dibagi menjadi beberapa kelompok, masing-masing kelompok diberi materi untuk didiskusikan; (c) guru membimbing jalannya diskusi; (d) siswa mempresentasikan hasil diskusi; (e) pemberian penghargaan dalam proses pembelajaran. Untuk mengetahui nilai siswa pada siklus I dapat dilihat pada tabel satu di atas.

Berdasarkan tabel dua di atas, dapat diketahui terdapat perbaikan atau peningkatan yang baik pada penguasaan konsep matematika siswa. Hal ini dapat dilihat bahwa dari 32 siswa hanya terdapat tiga siswa yang nilai di bawah KKM yaitu dua siswa dengan interval nilai 30-39 dan satu siswa dengan nilai 63 dan sisanya memperoleh nilai di atas KKM.

Model pembelajaran kooperatif tipe STAD yang dilaksanakan guru telah mampu menumbuhkan dan meningkatkan motivasi belajar siswa sehingga penguasaan konsep matematika siswa kelas III meningkat pula. Hal ini didukung oleh hasil penelitian Eminingsih (2013) yang menyatakan bahwa, model pembelajaran kooperatif tipe STAD mampu meningkatkan hasil belajar matematika siswa SMP.

Tanggapan siswa terhadap model pembelajaran kooperatif tipe STAD cukup beragam, tetapi hampir semuanya menyatakan bahwa mereka menyukai model belajar mengajar ini, hal ini dilakukan oleh melalui pertanyaan guru saat bertanya kepada para siswa di kelas. Selain itu dengan penerapan model ini, secara garis besar siswa merasakaan, yaitu: (a) siswa dapat semakin berinteraksi dengan guru dalam aktif bertanya, menyangga suatu pendapat ataupun mengoreksi kekeliruan guru dalam menjelaskan; (b) siswa menjadi lebih bertanggung jawab terhadap tugas-tugasnya sebagai seorang pelajar; (c) siswa bertambah kemampuan kognitifnya, paham akan materi yang disampaikan guru; (d) siswa juga lebih aktif bekerja sama menghadapi kesulitan-kesulitan belajar matematika dengan saling membantu satu sama lainnya.

Berdasarkan hasil di atas, secara keseluruhan penelitian tidakan kelas mengenai model pembelajaran kooperatif tipe STAD pada pelajaran matematika kelas III materi operasi hitung campuran dapat dikatakan berhasil karena pada akhir penelitian kriteria keberhasilan yang ditetapkan telah terpenuhi yaitu dapat meningkatkan hasil belajar siswa sesuai dengan KKM yang ditentukan.

\section{KESIMPULAN}

Dari penelitian tindakan kelas yang telah dilaksanakan pada siswa kelas III SDN Kapuk Muara 01 ini, maka dapat disimpulkan sebagai berikut: (a) dengan meningkatkan keaktifan siswa dalam pembelajaran akan dapat meningkatkan penguasaan konsep materi operasi hitung campuran, (b) pembelajaran kooperatif tipe stad merupakan model pembelajaran yang efektif untuk menyampaikan materi operasi hitung campuran, (c) pembelajaran kooperatif tipe stad mampu meningkatkan kemampuan pemecahan masalah matematika selain itu model pembelajaran ini membuat kerja sama diantara siswa dapat tercipta dengan lebih baik lagi, (d) penggunaan lembar kerja untuk membuat siswa agar aktif dalam belajar merupakan langkah yang efektif bagi siswa, karena dapat bersosialisasi 
dan saling tukar informasi dan ide langkah-langkah kerja untuk menyelesaikan suatu masalah dengan teman sebayanya.

\section{REFERENSI}

Arikunto,S., Suhardjono, \& Supardi.(2015). Penelitian Tindakan Kelas. Jakarta: Bumi Aksara.

Aqib, Z., Diniati, E., Jaiyaroh, S., \& Khotimah, K. (2008). Penelitian Tindakan Kelas untuk Guru SMP, SMA, SMK. Bandung: Yrama Widya.

Eminingsih. (2013). Peningkatan Hasil Belajar Matematika Melalui Pembelajaran Kooperatif Tipe STAD pada Siswa kelas VII E SMP Negeri 3 Batang. Lembar Ilmu Kependidikan, 1(42), 30-35.

Firmansyah, E. (2016). Peningkatan Kemampuan Pemahaman Matematika melalui Metode Pembelajaran Kooperatif Tipe STAD (Student Teams Achievement Divisions). Jurnal Ilmu Pendidikan (JIP) STKIP Kusuma Negara, 7(2), 1-17.

Kemmis, S., McTaggart, R., \& Nixon, R. (2013). The Action Research Planner: Doing Critical Participatory Action Research. Springer Science \& Business Media.

Nurimani, N. (2016). Pengaruh Pendekatan Open-Ended dengan Pembelajaran Kooperatif Tipe STAD terhadap Kemampuan Pemahaman dan Koneksi Matematis Siswa Ditinjau dari Self-Efficacy. Jurnal Ilmu Pendidikan (JIP) STKIP Kusuma Negara, 7(2), 1-19.

OECD. (2016). Programme for International Student Assessment (PISA) Result from PISA 2015 [PDF file]. Retrieved from https://www.oecd.org/pisa/PISA2015-Indonesia.pdf

Sugiyono, (2015). Metode Penetian Tindakan Komprehensif. Bandung: Alfabeta.

Widyantini, T. (2008). Penerapan Pendekatan Kooperatif STAD dalam Pembelajaran Matematika SMP. Yogyakarta: PPPPTK.

Zuhriyah, A. (2017). Pendekatan Pembelajaran Kooperatif Tipe Student Team Achievement Division (STAD) untuk Meningkatkan Kemampuan Penalaran Matematika. Jurnal Ilmu Pendidikan (JIP) STKIP Kusuma Negara, 8(2), 1-15. 